\title{
Spatial Analyses of Viral Epidemics in Australian Hop Gardens: Implications for Mechanisms of Spread
}

\author{
Sarah J. Pethybridge and Calum R. Wilson, Tasmanian Institute of Agricultural Research, University of Tasma- \\ nia, School of Agricultural Science, GPO Box 252-54, Hobart, Tasmania, 7001, Australia; Francis J. Ferrandino, \\ The Connecticut Agricultural Experiment Station, P.O. Box 1106, New Haven 06504; and Grey W. Leggett, Aus- \\ tralian Hop Marketers, GPO Box 104A, Hobart, Tasmania, 7001, Australia
}

\begin{abstract}
Pethybridge, S. J., Wilson, C. R., Ferrandino, F. J., and Leggett, G. W. 2000. Spatial analyses of viral epidemics in Australian hop gardens: Implications for mechanisms of spread. Plant Dis. 84:513-515.

Plant-to-plant spread of Hop mosaic virus (HpMV), Hop latent virus (HpLV), and Prunus necrotic ringspot virus (PNRSV) were monitored in two commercial hop gardens of cv. Victoria in Australia. At site 1, the cultural practice of mowing to remove excess basal growth operated exclusively along rows, while at site 2 , mowing occurred both along and across rows. Other cultural practices such as stringing, bine-training, spraying, and harvesting were directed along rows at both sites. Spatial aggregation within and across rows was assessed by ordinary runs analysis, and by radial correlation analysis using the program 2DCORR. The dominant spread mechanism of carlaviruses differed between sites. At site 1, along-row aggregation of both $\mathrm{HpLV}$ and HpMV in 1997 reflected the importance of basal-growth intertwining for virus transmission, either due to mechanical transmission or movement of apterous or alatae vectors along rows. At site 2, the random incidence of HpLV and HpMV reflected spread by alatae vectors. The spread of PNRSV at both sites was associated with mowing direction. This study reports the first use of a modified version of radial correlation analysis.
\end{abstract}

Additional keywords: epidemiology, Humulus lupulus

Hops (Humulus lupulus L.) in Australia are commonly infected by Hop latent carlavirus (HpLV), Hop mosaic carlavirus (HpMV), and Prunus necrotic ringspot ilarvirus (PNRSV; 16), the apple (PNRSVA) and intermediate (PNRSV-I) serotypes. In the absence of the most efficient aphid vector of $\mathrm{HpLV}$ and HpMV, Phorodon humuli Shranck $(1,18)$, the spread of these viruses is presumably by other aphid species, mechanical transmission, or both.

The spread of PNRSV between Prunus spp. trees has been associated with diseased pollen and infections during pollination $(4,6,10,11,14)$. However, diseased pollen and the feedings habits of thrips have more recently been strongly implicated in tree-to-tree spread $(12,13)$. In hop plants, the role of diseased pollen in the spread of PNRSV had been discounted because spread can occur in areas without male hop plants (17). The autocorrelation pattern for within-row spread of PNRSV was also suggestive of the role of direct plant contact or, possibly, a non-airborne vector (23). Investigations implicating the role of the nematode Longidorus macro-

Corresponding author: S. J. Pethybridge E-mail: sarah_jp@postoffice.utas.edu.au

Accepted for publication 22 December 1999.

Publication no. D-2000-0303-01R

(c) 2000 The American Phytopathological Society soma (9) and the mite Vasates fockeui (20) in PNRSV spread remain unsubstantiated. Despite the instability of PNRSV in undiluted sap, mechanical transmission of PNRSV was considered the most likely means of transmission (22). Glasshouse trials have suggested that the spread of PNRSV may occur by mechanical transmission during cultural operations, such as mowing and pruning (2) and training and harvesting $(7,22)$, or through direct foliage contact and root grafting (7).

A recent shift in the Australian hop industry from the traditionally grown $\mathrm{cv}$. Pride of Ringwood to higher-yielding triploid varieties (e.g., cv. Victoria) was associated with a sixfold increase in the rate of PNRSV spread (19). By determining how viruses spread among hop plants, an effective and economical control option may be formulated. In this study, we examined the spatial characteristics of HpLV, HpMV, and PNRSV epidemics in Australian hop gardens and assessed the influence of cultural operations on virus spread.

\section{MATERIALS AND METHODS}

Field plots. Two plots of cv. Victoria were established with virus-free plants. Plot $1(n=1,275)$ was planted in 1989 on a commercial farm at Bushy Park, Tasmania, Australia and arranged in a planting of 51 by 25 with $1.8 \mathrm{~m}$ between plants and $2.1 \mathrm{~m}$ between rows. At the Bushy Park site, all cultural practices (i.e., mowing, stringing, bine-training, and harvesting) were exclu- sively along rows, which encouraged extensive contact of basal growth between neighboring plants along rows. At approximately midseason, when plants had reached the top of the framework $(5.5 \mathrm{~m})$, the plot was grazed by sheep, which removed all basal growth and lower laterals to a height of approximately $1 \mathrm{~m}$. Plot 2 ( $n$ $=500$ ) was planted in 1994 with virus-free material on a commercial farm at Myrtleford, Victoria, Australia, and was planted in a lattice of 25 by 20 with $2.1 \mathrm{~m}$ separating plants within and between rows. At this site, mowing operated both along and across rows throughout the cropping season. This kept basal growth minimal and prevented adjacent-plant contact.

Serological testing. Collections of six expanding leaves from individual plants in plot 1 during spring of 1996 and 1997 and plot 2 during 1998 were tested by doubleantibody sandwich enzyme-linked immunosorbent assay (DAS-ELISA; 5), using polyclonal antisera to $\mathrm{HpMV}$ and HpLV. For PNRSV, polyclonal antisera to Chestnut mosaic virus and Rose mosaic virus 3 were used, which detected the apple and intermediate, and intermediate and cherry, serotypes, respectively (3). Plot 1 was tested initially in 1990 for HpMV and PNRSV. Sap was extracted and tested in duplicate wells with the appropriate positive, negative, and buffer controls per plate (5). Absorbance values $\left(\mathrm{A}_{405} \mathrm{~nm}\right)$ were obtained using a Titertek Multiskan Immunoplate Reader (Flow Laboratories, Helsinki, Finland). Absorbance values greater than three times the standard deviation of the mean of the negative controls were considered positive.

Spatial analysis. Data in both plots were characterized by ordinary runs (15) and radial correlation analyses (8). Ordinary runs analysis assessed the proportion of both along and across rows exhibiting significant $(P=0.05)$ clustering. Rows in either direction were combined with the last plant of row $i$ considered contiguous to the first plant of row $i+1$. A run was defined as a succession of one or more healthy or infected plants followed or preceded by the opposite infection state in an ordered sequence (15). Ordinary runs analyses were performed with Microsoft Excel. Radial correlation analysis was conducted by the program 2DCORR, which measured the probability of deviation from a random spatial distribution by a 
Kolmogorov-Smirnov-type analysis, based on a cumulative probability density function for the total number of infected-infected plant pairs within a given distance. The distance $r$ was an estimate for the length scale over which disease was correlated (8). Comparisons to ordinary runs analyses were made by examination of the down-row and across-row probability values (without the application of a Bonferroni correction).

2DCORR was modified to account for high disease incidence $(>50 \%)$. When more than half of the plants are infected, a certain number of plant pairs are infected irrespective of the spatial arrangement of infected plants. This effectively reduced the degrees of freedom in the KolmogorovSmirnov analysis by the total number of predetermined infected plant pairs. The cumulative difference between the observed and expected number of infected pairs is the same; therefore, the reduction in the degrees of freedom increased the power of the Kolmogorov-Smirnov test (21). Spatial distributions were not analyzed by either method if the disease incidence was $<5 \%$ or $>95 \%$.

\section{RESULTS}

An initial survey in plot 1 in 1990 found $2.1 \%$ of plants infected by PNRSV and $0.8 \%$ infected by HpMV (personal com-

Table 1. Temporal disease progress in Plot 1 (Bushy Park, Tasmania) and disease incidence in Plot 2 (Myrtleford, Victoria)

\begin{tabular}{lcccc}
\hline & \multicolumn{4}{c}{ Disease incidence (\%) } \\
\cline { 2 - 5 } Virus $^{\mathbf{a}}$ & Plot 1, 1990 & Plot 1, 1996 & Plot 1, 1997 & Plot 2, 1998 \\
\hline HpLV & $\mathrm{nt}^{\mathrm{b}}$ & 64.6 & 88.1 & 16.8 \\
HpMV & 0.8 & 59.9 & 77.3 & 11.6 \\
PNRSV & 2.1 & 66.4 & 91.7 & 31.4 \\
\hline
\end{tabular}

${ }^{\mathrm{a}} \mathrm{HpLV}=$ Hop latent virus, $\mathrm{HpMV}=$ Hop mosaic virus, and PNRSV = Prunus necrotic ringspot virus.

${ }^{\mathrm{b}}$ Not tested.

Table 2. Spatial test for aggregation of infected plants by ordinary runs analysis in plot 1 (1996 and 1997) and plot 2 (1998)

\begin{tabular}{lrcccc}
\hline Virus, year & $\begin{array}{c}\text { Infected } \\
\text { plants }\end{array}$ & $\begin{array}{c}\text { Total } \\
\text { plants }\end{array}$ & $\begin{array}{c}\text { Expected } \\
\text { runs }\end{array}$ & $\begin{array}{c}\text { Observed runs } \\
\text { (along/across rows) }\end{array}$ & $\begin{array}{c}\text { Z-statistic } \\
\text { (along/across rows) }\end{array}$ \\
\hline Plot 1 & & & & & \\
HpLV-1996 & 824 & 1,275 & 583.94 & $215 / 537$ & $-22.61 /-2.88$ \\
HpLV-1997 & 1124 & 1,275 & 267.23 & $175 / 243$ & $-12.93 /-3.26$ \\
HpMV-1996 & 765 & 1,275 & 613.39 & $422 / 554$ & $-11.14 /-3.44$ \\
HpMV-1997 & 987 & 1,275 & 449.08 & $327 / 429$ & $-9.69 /-1.56$ \\
PNRSV-1996 & 843 & 1,275 & 572.26 & $387 / 521$ & $-11.71 /-3.26$ \\
PNRSV-1997 & 1167 & 1,275 & 195.38 & $151 / 191$ & $-8.08 /-0.71$ \\
Plot 2 & & & & & \\
HpLV-1998 & 84 & 500 & 140.10 & $131 / 132$ & $-1.54 /-1.41$ \\
HpMV-1998 & 59 & 500 & 105.11 & $103 / 102$ & $-0.45 /-0.66$ \\
PNRSV-1998 & 155 & 500 & 214.90 & $139 / 140$ & $-7.95 /-7.84$ \\
\hline
\end{tabular}

${ }^{\mathrm{a}} \mathrm{HpLV}=$ Hop latent virus, $\mathrm{HpMV}=$ Hop mosaic virus, and PNRSV $=$ Prunus necrotic ringspot virus.

${ }^{\mathrm{b}}$ Z-statistic $=($ observed number of runs $+0.5-$ expected number of runs $) /$ standard deviation, with rows treated as contiguous. If $Z$-statistic is less than $-1.64(P=0.05)$, the row of plants had a nonrandom sequence of infected and healthy plants.

Table 3. Spatial test for aggregation of infected plants by radial correlation analysis in plot 1 (1996 and 1997) and plot 2 (1998)

\begin{tabular}{cccc}
\hline Virus, year $^{\mathbf{a}}$ & Radial spatial correlation $^{\mathbf{b}}$ & Down-row significance $^{\mathbf{c}}$ & Across-row significance $^{\mathbf{c}}$ \\
\hline Plot 1 & & & \\
HpLV-1996 & 15 & $2.22 \times 10^{-16}$ & 0.002 \\
HpLV-1997 & 14 & $2.22 \times 10^{-16}$ & 0.012 \\
HpMV-1996 & 18 & $2.22 \times 10^{-16}$ & 0.021 \\
HpMV-1997 & 15 & $2.22 \times 10^{-16}$ & 0.953 \\
PNRSV-1996 & 15 & $2.22 \times 10^{-16}$ & $5.85 \times 10^{-6}$ \\
PNRSV-1997 & 34 & $5.55 \times 10^{-16}$ & 0.539 \\
Plot 2 & & & \\
HpLV-1998 & $\mathrm{ns}$ & 0.529 & 0.049 \\
HpMV-1998 & $\mathrm{ns}$ & 0.823 & 0.210 \\
PNRSV-1998 & 7 & $1.78 \times 10^{-15}$ & $1.54 \times 10^{-13}$ \\
\hline
\end{tabular}

${ }^{\mathrm{a}} \mathrm{HpLV}=$ Hop latent virus, $\mathrm{HpMV}=$ Hop mosaic virus, and $\mathrm{PNRSV}=$ Prunus necrotic ringspot virus.

${ }^{\mathrm{b}}$ Radial spatial correlation is significant if there were more plant pairs (either healthy or infected) than expected within $r$ plant separation units in all directions; ns = not significant.

c Probability values from the 2DCORR probability matrix (8) for expected verses observed like pairs of adjacent plants (infected-infected or healthy-healthy plant pairs) either down row or cross row. munication, D. Munro, Department of Primary Industries, Water and Environment, Tasmania, Australia). Spread of all three viruses in plots 1 and 2 was rapid (Table 1).

Ordinary runs analyses of epidemics in plot 1 in 1996 indicated that plants infected by all three viruses were strongly clustered along rows, with lesser, but significant, aggregation across rows (Table 2). This was supported by results from radial correlation analysis, which detected significant spatial correlation in epidemics of $\operatorname{HpLV}(r=15)$, HpMV $(r=18)$, and PNRSV $(r=15)$ (Table 3). In 1997, the distribution of plants infected by all three viruses was again strongly aggregated along rows, with lesser, but significant, aggregation across rows (Table 2). Radial correlation analysis detected significant spatial correlation in epidemics of $\mathrm{HpLV}(r$ $=14), \operatorname{HpMV}(r=15)$, and PNRSV $(r=$ 34) in 1997 (Table 3).

In plot 2, results from both ordinary runs analysis (Table 2) and radial correlation analysis (Table 3) suggested that the distribution of HpLV- and HpMV-infected plants was random. In addition, similar analyses of PNRSV revealed significant $(P=0.05)$ clustering both along and across rows (Table 2). Radial correlation analysis of epidemics in plot 2 also revealed significant spatial correlation of PNRSV ( $r=7$; Table 3).

\section{DISCUSSION}

The spread of PNRSV in cv. Victoria was six times faster than previously reported in the traditionally grown Australian cv. Pride of Ringwood (16). The low infection levels and random distribution of infected plants recorded in the preliminary survey in plot 1 suggested either a small proportion of the planting material was virus infected, or, in the case of HpMV, spread by alatae vectors. Although no test for HpLV was conducted in 1990, the high level of infection found in 1996 suggests that it was also present.

Spatial analyses of incidence suggested that the spread of PNRSV in both plots was associated with the mowing of basal growth. In plot 1, PNRSV incidence in 1996 and 1997 was predominantly autocorrelated along rows, suggesting spread by mowing, plant intertwining, or both. The lesser amount of across-row aggregation may reflect coalescing of existing foci or spread by initial basal growth intertwining prior to the first mowing. In glasshouse trials, plant intertwining and pruning, to simulate mowing, have been shown to facilitate transmission of PNRSV to virusfree hop plants at low frequencies. In further glasshouse trials, root grafting has also transmitted PNRSV from infected to virusfree hop plants (S. J. Pethybridge, C. R. Wilson, and G. W. Leggett, unpublished data). However, the extent to which root grafting occurs in hop gardens in Australia is unknown. 
Differences in spatial characteristics of epidemics of HpLV and HpMV were identified between the two sites, which may reflect differences in dominant spread mechanisms. Epidemics of $\mathrm{HpLV}$ and HpMV in plot 1 in 1996 and 1997 showed a high proportion of along-row aggregation of diseased plants and some significant aggregation across rows. This may reflect the possibility that spread of both viruses in 1996 and 1997 was influenced by basal growth contact early in the season. This may have facilitated mechanical transmission, through mowing or movement of alatae or apterous aphid vectors between infected and healthy plants along rows.

Results from both ordinary runs and radial correlation analyses concluded that the distribution of plants infected with either HpLV and HpMV in plot 2 was random, suggestive of spread by alatae aphid vectors.

Spatial analysis of viral epidemics in Australian hop gardens has proven useful in elucidating mechanisms of spread. The importance of basal growth and mowing to virus spread suggests that alternative methods of basal growth control, such as desiccant herbicides, should be investigated as a means of reducing spread.

\section{ACKNOWLEDGMENTS}

We thank D. Munro, Department of Primary Industries, Water and Environment, Tasmania, for 1990 incidence data in plot 1; S. Nelson, Cooperative Extension Service, Hawaii, for spatial analysis advice; D. Barbara, Horticultural Research International, United Kingdom, for generous gifting of Chestnut mosaic virus and Rose mosaic virus 3 antisera; R. Klein, Washington State University at Prosser, for generous gifting of Hop mosaic virus antisera; and L. Sherriff, Australian Hop Marketers, and F. Hay, Tasmanian
Institute of Agricultural Research, for constructive discussion.

\section{LITERATURE CITED}

1. Adams, A. N., and Barbara. D. J. 1980. Host range, purification and some properties of hop mosaic virus. Ann. Appl. Biol. 96:201-208.

2. Anonymous. 1980. Research results of the Bavarian Institute for Soil Culture and Plant Production, Division Hops. Page 10 in: Bavarian Inst. Soil Cult. Plant Prod. Ger. Soc. Hop Res. Annu. Rep.

3. Barbara, D. J., Clark, M. F., and Thresh, J. M. 1978. Rapid detection and serotyping of Prunus necrotic ringspot virus in perennial crops by enzyme-linked immunosorbent assay. Ann. Appl. Biol. 90:395-399.

4. Cameron, R. R., Milbraith, J. A., and Tate, L. A. 1973. Pollen transmission of Prunus necrotic ringspot in prune and sour cherry orchards. Plant Dis. Rep. 57:241-243.

5. Clark, M. F., and Adams, A. N. 1977. Characteristics of the microplate method of enzyme-linked immunosorbent assay for the detection of plant viruses. J. Gen. Virol. 34:475-483.

6. Cole, A., Mink, G. I., and Regev, S. 1982. Location of Prunus necrotic ringspot virus on pollen grains from infected almond and cherry trees. Phytopathology 72:1542-1545.

7. Eppler, A., and Dahdahbiglou, R. 1991. Experiments on the non-vectorial transmission of PNRV in hops. Med. Fac. Landbouww. Rijksuniv. Gent 56:577-587.

8. Ferrandino, F. J. 1998. Past nonrandomness and aggregation to spatial correlation: 2DCORR, a new approach for discrete data. Phytopathology 88:84-91.

9. Fritzsche, R., and Kegler, H. 1968. Nematoden als vectoren von viruskrankteiten der obstgehotze. Tag. Ber. D. Akad. Land. Wiss. DDR. 97:289-295.

10. George, J. A., and Davidson, T. R. 1963. Pollen transmission of necrotic ringspot and sour cherry yellows viruses from tree to tree. Can. J. Plant Sci. 43:276-288.

11. George, J. A., and Davidson, T. R. 1964. Further evidence of pollen transmission of necrotic ringspot and sour cherry yellows viruses in sour cherry. Can. J. Plant Sci. 44:383384.

12. Greber, R. S., Klose, M. J., Milne, R. S., and Teakle, D. S. 1991. Transmission of Prunus necrotic ringspot virus using plum pollen and thrips. Ann. Appl. Biol. 118:589-593.

13. Greber, R. S., Teakle, D. S., and Mink, G. I. 1992. Thrips-facilitated transmission of prune dwarf and Prunus necrotic ringspot viruses from cherry pollen to cucumber. Plant Dis. 76:1039-1041.

14. Kelly, R. D., and Cameron, H. R. 1986. Location of prune dwarf and Prunus necrotic ringspot virus in sweet cherry pollen and fruit. Phytopathology 76:317-322.

15. Madden, L. V., Louie, R., Abt, J. J., and Knoke, J. K. 1982. Evaluation of tests for randomness of infected plants. Phytopathology 72:195-198.

16. Munro, D. 1987. Viruses infecting hop, $\mathrm{Hu}$ mulus lupulus in Australia. Aust. J. Agric Res. 38:83-90.

17. Neve, R. A., and Thresh, J. M. 1984. Prunus necrotic ringspot virus in hops. English Hops $1: 6-7$.

18. Paine, J., and Legg, J. T. 1953. Transmission of hop mosaic by Phorodon humuli (Shranck). Nature 171:263-264.

19. Pethybridge, S. J., Wilson, C. R., and Leggett, G. W. 1997. Virus incidence and spread in Australian triploid hops. Acta Hortic. 471:105-110.

20. Proesler, G. 1968. Ubertragungsverusche mit dem latenten prunus-virus und der gallmilbe Vasates fockeiu Nal. Phytopathol. Z. 63:1-9.

21. Sokal, R. R., and Rohlf, F. J. 1981. Pages 716-721 in: Biometry, 2nd ed. W. H. Freeman \& Co., San Francisco.

22. Thresh, J. M., Barbara, D. J., and Ormerod, P. J. 1988. The incidence and spread of Prunus necrotic ringspot virus in English hop plantings. Pages 71-82 in: Proc. Int. Workshop Hop Virus Dis. Giessen.

23. Thresh, J. M., and Ormerod, P. J. 1973. Virus diseases of hop-spread of Prunus necrotic ringspot virus in hop. rep. east Malling Res. Stn. 1972:163-164. 